\title{
Gender dan Emansipasi Perempuan dalam Pendidikan Islam
}

\section{Achmad Faisol Haq}

IAI Uluwiyah Mojosari Mojokerto

Email : faisolhaq01@gmail.com

Article History:

Received : 09-02-2020

Revised : 20-02-2020

Accepted : 05-03-2020

\begin{abstract}
The Islamic education problems that are often criticized by the West are gender issues, Islamic education is considered west to overrule the role of women in Islamic education, whereas in Islamic education since the beginning of Islam Strongly uphold women's standing, especially in terms of inheritance and the similarity of rights and obligations in science. In modern eras of women's emancipation movement in Islam are more likely to follow the western mindset, the activists of Islamic feminism could take a pattern of the Muslim philosopher Greek Helereism, as in classical Islam the Muslim philosopher could put aside the philosophical thought of Greek Helenism that was incompatible with the teachings of Islam, as well as to take the thought of Helenism Greek that matched the spirit of Islam. This article is an explanation of the gender movements and emancipation of women in particular in Islamic education. It is important to reconstruct the fundamentals of Islamic perspectives, because Islam has a universal view and equal rights in education between men and women is the same as other aspects and gender should be the same. Influenced by Islamic spiritual, especially in the rules of education for Muslims.
\end{abstract}

Keyword : Gender, Emansipation Women, Islamic Education.

\section{Pendahuluan}

Masalah gender lazim penjadi kritik terdahap pendidikan Islam, probematika Pendidikan Islam yang menjadi sorotan Barat adalah masalah kesetaran gender serta partisipasinya dalam pendidikan Islam. Isu ini kemudian menjadi kritik terhapa pendidikan Islam yang dianggap tidak memiliki ruang yang sama dengan kaum laki-laki dalam pendidikan Islam. Karena sebagian besar ajaran Islam dianggap terlalu maskulin dan lebih berpihak kepada kaum laki-laki. Kritik yang dilontarkan oleh gender dunia kepada pendidikan Islam ini bukanlah hal yang baru, bahkan bukan hanya dalam agama Islam saja, bahkan dalam prespektif sejarah umat manusia perbedaan peran serta status antara laki-laki dan perempuan menjadi menjadi perhatian dan menjadi salah satu masalah yang utama dunia ini. 
Jika melihat dalam konteks historis pendidikan Islam, sesungguhnya secara jelas bahwa dalam pendidikan Islam tidak membedakan peran antara laki-laki dan perempuan, keduanya memiliki kesamaan hak serta peranannya dalam pendidikan Islam, hal ini bisa kita lihat dari berbagai literatur. Ajaran Islam memandang bahwa lakilaki dan perempuan memiliki memilki porsi yang sama dalam menjalankan kewajibanya sebagai hamba. Untuk sampai pada derajat Muttaqun, untuk bisa mencapai derajat ini Islam tidak membeda antara jenis kelamin laki-laki maupun perempuan ataupun membedakan suku bangsa atau etnis tertentu. Al Qur'an menjelaskan hamba yang ideal adalah hamba yang Muttaqun (Q.S Al Hujurat ayat 13), dalam kapasitasnya sebagai hamba laki-laki dan perempuan akan mendapatkan perhargaan dari Allah sesuai dengan kadar pengabdianya (Q.S Al- Nahl ayat 97). ${ }^{1}$

Al-Qur'an merupakan kitab suci umat Islam yang menjunjung tinggi derajat perempuan sesuai dengan derajat laki-laki, sesuai dengaan derajat manusia yang universal, bahkan Al-Qur'an dipandang sebagai kitab suci yang lebih menghormati perempuan jika dibandingkan dengan dogma-dogma agama lainya. Hal ini menunjukan bahwa pembahasan perempuan menjadi wacana yang menarik dalam ajaran Islam, bahkan dijadikan nama surat didalam Al-Qur'an yaitu surah An-Nisa'. Karena memang realitas sejarah sebulum kemunculan Islam, masyarakat jahiliyah sangat memandang rendah perempuan bahkan perempuan pada saat itu bisa menjadi "barang" yang diwariskan.

Dalam konteks pendidikan secara global, tidak bisa dilepaskan dengan isu-isu kesetaraan gender, terutama kesetaraan antara laki-laki dalam pendidikan, gerakan emansipasi perempuan secara terus menerus meyuarakan suaranya agar perempuan mendapatkan kesetaraan dan persamaan hak dalam pendidikan, dan perempuan dapat memperoleh dan berkiprah dalam dunia pendidikan. ${ }^{2}$

\section{Gender dan Jenis Kelamin Dalam Terminologi}

Membahas Gender tidak pernah lepas dari jenis kelamin laki-laki dan perempuan. Dalam Women's Studies Ensyclopedia menjelaskan bahwa gender merupakan kultural yang mencoba untuk membedakan antara laki-laki dan perempuan dalam hal peran, mentalitas dan karakeristik antara laki-laki dan perempuan yang berkembang dalam suatu masyarakat, dari pemaparan ini masih bersifat sangat global, yang menyamakan gender dengan seks. ${ }^{3}$

Membicarakan antara laki-laki dan perempuan kiranya ada dua aspek pokok yang harus dibahas dalam hal ini, pertama seks (jenis kelamin) dan gender. Aspek pertama adalah jenis kelamin, aspek ini adalah perbedaan yang didasarkan pada aspek fisik manusia. Perbedaan ini melekat pada manusia sejak lahir dan bersifat permanent, hal ini ditentukan oleh Tuhan dan melekat pada diri manusia dan diterima oleh manusia

1 Nasaruddin Umar, Argumen Kesetaraan Jender Prespektif al-Qur'an, (Jakarta: Paramadina, 1999), 248-249.

2 Zainal Abidin, "Kesetaraan Gender dan Emansipasi Perempuan dalam Pendidikan Islam", Jurnal Tarbawiyah Vol. 12 No. 01 (Januari 2015), 3.

${ }^{3}$ Eni Purwati \& Hanun Asrohah, Bias Gender dalam Pendidikan Islam, (Surabaya: Alpha, 2005), 13-14. 
secara apa adaya, sehingga ketentuan ini biasa disebut dengan kodrat. Menurut kodratnya laki-laki memiliki penis, jakung dan mengelurkan sperma, sedangkan perempuan memilki alat reproduksi atau rahim, memproduksi sel telur, vagina dan memiliki lata untuk menyusui.

Aspek yang kedua dilihat dari aspek gender, aspek ini berbeda dengan aspek yang pertama, kalau aspek yang pertama secara kodrat sedangkan aspek yang kedua gender dilihat dari bangunan kuntruksi sosial yang berkembang pada suatu masyarakat, perbedaan jenis kelamin tersebut akhirnya membentuk perbedaan-perbedaan secara psikologis, perbedaan tersebut kemudian dikuatkan dan dikembagkan melalui pembelajaran lingkungan, pembelajaran tersebut dibentuk, dikuatkan dan diasosiasikan bahkan dikontruksikan secara sosial atau kultul melalui ajaran agama atau negara. ${ }^{4}$

Ketika melihat gender dari dua aspek tersebut yang terjadi adalah sebuah kerancuan dan pemutaranbalikan makna tentang apa yang disebut sebagai jenis kelamin dan apa yang disebut gender. Pemahaman yang tidak sesuai dengan makna yang terjadi pada masyarakat tentang apa yang seharusnya itu disebut sebagai kodrat malah sebaliknya disebut sebagai sebuah kontruksi sosial. Apa yang seharusnya disebut sebagi kodrat yang berarti ketentuan biologis, justru pada dewasa ini disebut sebagai "kodrat wanita" adalah sebuah kultrul atau atau kontruksi sosial atau gender.

Coba kita ambil contoh dalam permasalah ini, misalnya sering diungkapkan bahwa mendidik anak, mengelolah dan merawat kebersihan rumah adalah sebuah tugas dari perempuan. Padahal pemahaman yang seperti itu, mendidik anak, mengelolah dan merawat kebersihan rumah bukanlah sebuah kodrat wanita, akan tetapi sebuah bangunan kontruksi sosial yang terjadi pada masyarakat tertentu. Oleh karena itu boleh jadi urusan mendidik anak, merawat dan mengelolah keluarga bisa jadi menjadi tugas dari laki-laki. Dalam hal ini tugas tersebut bisa dipertukarkan dan tidak bersifat universal, apa yang sering disebut sebagai kodrat wanita atau takdir tuhan pada wanita dalam mendidik rumah tanggah dan mendidik anak sesungguhnya adalah gender. ${ }^{5}$

Gender merupakan konsep klasifikasi sifat maskulin (laki-laki) dan feminim (perempuan) yang dibentuk oleh sosio kultur, pendapat ini sejalan dengan pendapat pada umumnya kaum feminis yang berpendapat bahwa gender merupakan ketentuan masyarakat mengenai seseorang yang lahir dengan sifat kelaki-lakian (maskulin) atau sifat keperempuanan (feminis) adalah termasuk dari bidang kajian gender. ${ }^{6}$

Dari sini kita coba ambil sebuah kesimpuan bahwa permasalahan tentang gender bukan mengenai permasalahan yang dilihat dari jenis kelamin saja, akan tetapi permasalahan gender timbul juga karena ada sebuah kontruksi sosial yang terjadi pada suatu masyarakat yang diasosiasikan melalui ajaran agama atau negara, konsep yang seperti ini (konstruksi sosial) yang sudah berlangsung lama dan proses panjang sehinggah pemahaman gender yang seperti ini dianggap sebagai sebuah ketentuan

${ }^{4}$ Rendra Widyatama, Bias Gender dalam Iklan Televisi, (Yogyakarta: Mediaperssindo, 2006), 3.

${ }^{5}$ Mansour Fakih, Analisis Gender \& Tranformasi Sosial (Yogyakarta: Putaka pelajar, 1996), 10-11.

6 Siti Muslikhati, Feminisme dan Pemberdayaan Perempuan dalam Timbangan Islam (Jakarta: Gema Insani, 2004), 20. 
Tuhan. (Seolah-olah gender bersifat biologis yang tidak bisa diubah lagi, sehinggah perbedaan gender dianggap dan dipahami sebagai kodrat laki-laki dan perempuan).

Ketika permaslahan gender muncul dari sebuah kontruksi sosial maka yang terjadi adalah permasalahan gender merupakan hasil dari sebuah pemahaman masyarakat yang yang membedakan antara laki-laki dan perempuan.

Hal ini yang membuat kaum feminis mengungkapakan bahwa sesungguhnya permasalahan gender merupakan permasalahan yang dikontruksikan secara sosial dan budaya, dalam arti lain permasalahan ini berasal dari masyarakan itu sendiri bukan berasal dari ketentuan tuhan, Karena sesunguhnya fakta sosial menunjukkan dengan jelas bahwasanya yang selama ini dinggap sebagai sifat lelaki dapat diganti dan dipertukarkan atau berubah menurut jenjang waktu, tempat dan kelas sosial. Inilah yang disebut oleh kaum feminis sebagai perbedaan gender, dan atas dasar ini sebagaimana sesuatu yang bersifat sosial yang dibikin oleh manusia itu sendiri, maka ada kemungkinan-kemungkinan bagi manusia untuk mengubah atau menukarkanya sesuai dengan konteks kodratnya.

Dengan pemahaman yang seperti ini, seseorang boleh jadi berkesimpulan bahwa kalau begitu akan pembalikan peran antara laki-laki dan perempuan, perempuan harus berperan sama dengan laki-laki, akan tetapi kaum feminis menolak sebuah ungkapan yang seperti itu, dengan mengugat ideologi patriarki, tidak lantas berarti harus menerapkan ideologi matriarki. Sebenarnya yang ingin kaum feminis wujudkan adalah pola hubungan dan perlakuan antara laki-laki dan perempuan secara adil dan manusiawi.

Mansour Fakih dengan jelas menyatakan bahwa sesungguhnya perbedaan gender sebenarnya tidak akan menjadi masalah sejauh tidak menyebabkan ketidakadilan bagi peran antara perempuan dan laki-laki. Dengan memahami persoalan perbedaan gender yang sedemikian ini, diharapkan akan muncul pandangan yang lebih manusiawi dan lebih adil anatara peran laki-laki dan perempuan. Perempuan berhak memiliki akses yang sama dalam berpartisipasi di bidang pendidikan, politik, ekonomi, sosial dan intelektual serta pendapat perlakuan yang sama sebagaimana kaum laki-laki. Sebaliknya, kaum laki-laki juga bisa berpartisipasi penuh di rumah dan ikut juga merawat anak-anaknya. ${ }^{7}$

\section{Gender dalam Pendidikan Islam}

Hadist termashur dalam kaitanya dengan menuntut ilmu adalah "Menuntut Ilmu itu Wajib bagi setiap Muslim" (HR. Baihaqi), dalam hadist tersebut kata "muslim" dalam terminologi bahasa Arab dinyatakan sebagai Mudzakar (laki-laki) bukan sebagai Mu'annast (perempuan). Dalam riwayat lain hadist tersebut ditambahi dengan Muslimah, yang berarti menuntut ilmu itu wajib bagi kaum laki-laki dan perempuan. Al Sakhawai sebagaimana yang dikutip oleh Jonathan Berkey, mengungkapkan bahwasanya hadist yang redaksinya ditambahi dengan Muslimah itu statusnya kurang

7 Husein Muhammad, Fiqh Perempuan Refleksi Kiai atas Wacana Agama dan Gender, (Yogyakarta: LKIS, 2012), 7-9. 
kuat karena tidak didukung oleh perawi-rawi yang Tsiqah (terpecaya). Meskipun demikian bukan berarti perempuan tidak punya hak dan kewajiaban untuk menuntut ilmu sebagaimana laki-laki, para perawi hadist sepakat bahwasanya secara logis kata muslimah itu tersimpan dalam kata muslim, oleh karena itu menuntut ilmu dalam Islam untuk wajib hukumnya bagi Muslim (laki-laki) dan muslimah (perempuan).

Hal ini bisa dibuktikan dengan melihat dari historisnya, pada masa Nabi Muhammad perempuan mempunyai kecendrungan kuat untuk mendapatkan perlakuan yang sama dengan laki-laki dalam menuntut ilmu. Pernah suatu ketika sahabat-sahabat perempauan Nabi memohon kepada Nabi untuk meluangkan waktu tertentu dan khusus untuk para sahabat perempuan agar sahabat perempuan dapat menuntut ilmu dari Nabi, Nabipun menyisihkan waktu tertentu untuk para sahabat perempuan supaya bisa menuntut ilmu dari Nabi.

Sesungguhnya dalam ajaran Islam tidak membedakan antara laki-laki dan perempuan dalam hal menuntut ilmu, dalam ajaran Islam mewajibakan bagi laki-laki maupun perempuan untuk menuntut ilmu. Akan tetapi memang dalam prakteknya kesempatan untuk menuntut ilmu tidak sama antara kaum laki-laki dengan perempuan, dalam sejarahnya seolah-olah pendidikan hanya untuk kaum laki-laki saja, kesempatan untuk mengenyam pendidikan lebih banyak diperoleh kaum laki-laki. Pendidikan yang mencetak kader ulama', hakim, penggelola masjid, tenaga administrasi, pejabat publik, pejabat pemerintah dan lain sebagainya. Posisi-posisi diruang publik ini didominasi oleh kaum laki-laki, sedangkan untuk kaum perempuan kurang mendapatkan ruang untuk menduduki posisi publik.

Keterbatasan perempuan dalam hal menuntut ilmu dan keterbatasan perempuan untuk mendapatkan ruang diposisi ruang publik ini karena memang dalam kultur Arab tidak memberikan keluasan bagi perempuan untuk keluar rumah dan menggap tabu kehadiran perempuan ditengah-tengah laki-laki. Dominasi kaum laki-laki terhadap perempuan merupakan faktor terbatasnya peran perempuan dalam pendidikan. Bukan berarti pendidikan bagi perempuan tidak ada sama sekali akan tetapi faktor kultur sosial budaya yang memposisikan seolah-olah dunia pendidikan hanya untuk kaum lakilaki saja. ${ }^{8}$

Sejarah juga mencatat ada beberapa kelompok belajar bagi perempuan, akan tetapi pada waktu itu semuanya dilaksanakan secara terpisah. Mislanya Achmad bin Hambal melaksanakan pengajaran bagi kaum perepuan dilaksanakan pada waktu sore hari. Kelompok belajar bagi perempuan ini biasanya dilaksanakan di rumah-rumah yang masih mempunyai hubungan kerabat dengan ulama' tersebut. Sedangkan untuk perempuan yang bukan dari golongan kerabat ulama' biasanya mereka menuntut ilmu dari ayahnya sendiri atau biasanya mereka mendatangkan guru pribadi.

Pada sistem pendidikan Islam masa klasik, biasanya diadakan pemisahan antara laki-laki dan perempuan, pengajaran untuk perempuan biasanya dilakukan secara terpisah dengan siswa laki-laki dan biasanya diselenggarakan dirumah-rumah. Oleh

${ }^{8}$ Eni Purwati \& Hanun Asrohah, Bias Gender dalam Pendidikan Islam, 60-62. 
karena itu jumlah pendidikan formal bagi kaum perempuan pada masa itu jumlahnya sangat sedikit jika dibandingkan dengan pengajaran bagi kaum laki-laki.

Mengenai pendidikan perempuan, sesungguhnya ada data yang menyebutkan bahwasnya pernah dalam satu majlis yang terbuka berkumpul antara laki-laki dan perempuan, dan antara laki-laki dan perempuan diberi kesempatan yang sama untuk bertanya, misalnya majlis al-wa'dh yang terbuka bagi kaum laki-laki dan perempuan, akan tetapi menurut Muniruddin Ahmed sebagaimana yang dikutip oleh Hanun Asrohah menggap majlis tersebut sebagai tempat pertemuan bukan tempat pengajaran. ${ }^{9}$

Dari sini mungkin biasa diambil sebuah kesimpulan bahwasanya pada dasarnya memang dalam ajaran Islam tidak pernah membedakan antara kaum laki-laki dan perempuan dalam kaitanya dengan pendidikan, laki-laki dan perempuan memiliki hak dan kewajiban yang sama dalam dunai pendidikan, akan tetapi pada masa Islam klasik, perempuan yang bisa untuk mendatkan kesempatan pendidikan di ruang terbuka jumlahnya sangat sedikit jika dibandingkan dengan laki-laki.

Bagaimana dengan perempuan yang berada di Indonesia, perempuan Indonesia pada masa Kartini sangat sedikit sekali yang bisa merasakan pendidikan, sebagaimana yang diungkapkan oleh Gadis Arifia dalam Feminisme Sebuah Kata Hati yang memaparkan surat kartini pada 25 Mei 1899 sebagai berikut: "Kami anak-anak perempuan, diikat oleh adat istiadat dan kebiasaan, hanya boleh sedikit saja mendidipi kemajuan, terutama pada bidang pendidikan"10

Di Indonesia masalah pemerataan jumlah dan mutu pendidikan yang bersangkutan dengan gender. Hampir keterbelakangan Indonesia di bidang pendidikan bersifat meyeluruh, yang meliputi dua jenis yakni laki-laki dan perempuan, bahkan keterbelakangan ini lebih lagi ketika terjadi gejala yang cukup luas antara laki-laki dan perempuan. Perempuan masih jauh tertinggal jika dibandingkan dengan laki-laki. Namun permasalahanya bisa menjadi sangat ironis mengingat sejak semula, sejak masa awal-awal perlawanan melawan penjajah dan merebut serta memperjuangkan kemerdekaan, kaum perempuan Indonesia memilki kesempatan yang lebih besar jika dibandingkan dengan bangsa-bangsa lainya.

Oleh karena itu pemerataan mutu dan jumlah pendidikan harus semestinya ditujukan secara khusus bagi kaum perempuan, sehingga setara dengan kaum laki-laki. Perhatian yang besar sesungguhnya lebih kepada kaum perempuan, karena kaum perempuan lebih mempunyai nilai pendidikan tinggi. Sebagaimana seorang ibu yang memilki nilai kejiwaan lebih dekat dengan anak, jauh lebih dekat jika dibandngkan dengan seorang ayah. Disini bisa langsung terlihat mutu pendidikan bagi perempuan terutama seorang ibu langsung berdampak bagi seorang anak, hal ini bisa juga dikatan bahwa mendidikan seorang perempuan yang nantinya akan menjadi calon ibu itu sama dengan mendidik satu keluarga.

Hal sudah terbukti ketika bangsa-bangsa Eropa pada saat apa yang dinamakan 'ferormasi" agama. Pandangan reformasi yang menghendai adanya akses kepada kitab

\footnotetext{
${ }^{9}$ Hanun Asrohah, Sejarah Pendidikan Islam, (Jakarta: Logos, 1999), 96-98.

10 Gadis Arivia, Feminisme Sebuah Kata Hati (Jakarta: Kompas, 2006), 44.
} 
suci untuk semua pemeluknya, tidak hanya terkhususkan pada kaum para imam saja, telah mendorong adanya pemberantasan buta huruf, karena pada waktu di Eropa kaum laki-laki biasanya menghabiskan banyak waktunya untuk pergi ke ladang, konon yang lebih banyak waktu untuk mengikuti pendidikan pemberantasan buta huruf di Eropa adalah dari kalangan perempuan, dan angka "melek huruf" yang terjadi pada ibu-ibu di Eropa bisa menjadi sumber dorongan sumber dorongan pendidikan anak-nak di dalam rumah. ${ }^{11}$

\section{Konstruksi Pemikiran Feminisme dalam Islam}

Melihat kedudukan perempuan dalam Islam, maka kita juga harus melihat kedudukan perempuan pra-Islam di kawasan Arab atau katakanlah keadaan hukum Arab pra-Islam, karena dengan begitu kita akan melihat lebih objektif tentang konektifitas antara hukum Islam dan hukum Arab pra-Islam atau kondisi hukum normatif Arab Jahiliyah.

Dalam pergaulan hidup, Arab Jahiliyah mempunyai hukum tersendiri terntang perkawinan, hukum waris, dagang dan lain-lain. Dalam hal hukum perkawinan dan hukum waris, Arab Jahiliyah meletakan kaum perempuan pada posisi yang tidak berharga. Pada waktu itu pria boleh menikahi perempuan sebanyak-banyaknya tanpa mas kawin dan tanpa batas maksimal, sedangkan perempuan tidak menerima hak warisan atas harta orang tua atau keluarga yang meninggal, bahkan perempuan menjadi harta harisan itu sendiri. Maka dalam hukum warisan Islam memberi bagian warisan kepada perempuan, kalau tidak dipandang layak sama besarnya dengan bagian laki-laki atau setidaknya seperduanya. ${ }^{12}$

Gambaran tersebut menunjukkan bahwa dalam kesejaharan Islam telah mendekontruksi sebuah kebiasalan lama dalam hukum waris Arab pra-Islam dengan pendekatan yang lebih manusiawi dengan memposisikan perempuan dalam konteks hukum keluarga. Dalam sejarahnya juga mencatat sejak kemunculan memberikan bagian warisan kepada perempuan dalam ajaran Islam menimbulkan reaksi yang keras dari kalangan tokoh-tokoh Arab pra - Islam yang memegang teguh tradisi Arab Jahiliyah dengan memusuhi bahkan sampai juga menyatakan perang kepada Nabi Muhammad karena telah berani menodai ajaran nenek moyang mereka dengan memberikan bagian hak warisan kepada perempuan.

Setelah Islam datang, terjadilah gelombang perubahan terhadap pandangan stereotip terhadap perempuan yang sudah terjadi selama berabad-abad yang menjadi ttradisi Arab. Namun demukian, pada masa modernitas ini justru kritkan yang ditujukan kepada ajaran Islam. Terutama yang menyoroti ajaran Islam yang secara pejerotif membedakan bagian hak waris antara perempuan dan laki-laki. Menanggapi hal ini Muhammad Qutb mensinyalir adanya dua pandangan yang belum tentu benar tentang konsep tentang kedudukan perempuan yang kedua pendapat ini tidak sah. Pertama, Pandangan yang telah berpendapat bahwa Islam telah memberikan hak-hak yang sama

\footnotetext{
${ }^{11}$ Nurcholis Madjid, Indonesia Kita, (Jakarta: PT Gramedia Pustaka Utama, 2004), 162.

12 Muh. Zuhri, Hukum Islam dalam Lintasan Sejaran, (Jakarta: RajaGrafindo Persada, 1996), 5.
} 
antara laki-laki dan perempuan dalam segala hal. Kedua, Pandangan yang penuh dengan kejahiliaan yang telah berpandangan bahwa Islam adalam musuh perempuan, Islam telah menjatuhkan taraf dan kehormatan perempuan da banyak sekali statementstatement yang menyudutkan terhadap ajaran Islam. ${ }^{13}$ Kedua pandanga tersebut menurut Qutb dilatarbelakangi dengan ketidakpahaman mereka tentang hakikat ajaran Islam dan dengan sengaja mereka mencampu adukkan antara kebenaran dengan kebathilan.

Akan tetapi sinyal Qutb terhadap kedua hal tersebut menurut syahrin Harahap, kemungkinan kedua pandangan tersebut disematkan kepada kaum Orientalis dalam memandang hubungan antara timur dan Barat dalam isu-isu tentang mainstream gender. Karena bisa jadi sebagian kaum Orientalis, menuduh Islam pada abad pertengahan sangat mendeskriminatifkan perempuan sebagaimana yang terlihat dalam rumusan-rumusan Fiqh. Kemudian pandangan yang terlalu longgar seperti yang tergambar dalam pandangan bahwa perempuan itu memilki hak-hak dan kewajiabn yang sama dengan laki-laki dalam semua hal. Pandangan yang seperti ini dinggap sebagai pengaruh dari dunia Barat yang seringkali dianggap tidak mengindahkan martabat kaum perempuan. ${ }^{14}$

Terhadap masalah ini, Said Ramadhan mengungkapkan bahwa telah terjadi kekacauan dalam persepsi mengenai posisi perempuan terutama mengenai gerakan emansipasi perempuan yang akhirnya jauh dari semangat Islam, dikarenakan pengaruh yang kuat dan upaya meniru Barat sehingga menjauhkan diri dari upaya semangat membebaskan kaum perempuan yang sejak semula diperjuangkan oleh Nabi Muhammad, dan dampaknya telah memposiskan perempuan justru lebih rendah karena tidak menyadari derajat dan martabat khusus untuk perempuan sebagaimana dalam dimensi Al-Quran dan Hadist. 15

Berpijak dari pandangan Said Ramadhan ini, bahwa gerakan feminisme dalam Islam harus tetap dalam koridur semgat pembaruan kedudukan perempuan sebagaimana yang sejak awal sudah digariskan oleh Al-Qur'an dan Hadist, karena kalau gerakan feminisme dalam Islam dilakukan secara membabi-buta meniru Barat maka otomatis lambat laun akan merusak tatanan umat Islam itu sendiri akibat kehilangan jatidirinya sebagai seorang Muslimah. Karena dalam ajaran Islam menempatkan perempuan dalam posisi yang mulia dan agama Islam menyapa kaum perempuan dengan kelembutan dalam segala aspek.

Sejarah juga pernah mencatat bahwa pada masa Umar Ibn Khattab, pernah suatu ketika seorang perempuan beradu argumen dengan khalifah Umar didalam Masjid, dan pada waktu itu Umar Ibn Khattab mengakui kesalahanya dan membenarkan pendapat dari seorang perempuan itu, dalam sejarahnya juga pernah dari golongan perempuan menduduki posisi puncak dibidang politik dan militer, semisal Aisyah ra. Menjadi pelaku

13 Muhammad Qutb, Subhat Hawl al-Islam, terj. Salah Paham Terhadap Islam, (IIFSO, 1985), 140-142.

${ }^{14}$ Syahrin Harahap, Islam Dinamis Menegakkan Nilai-Nilai Ajaran Al-Qur'an dalam Kehidupan Modern diIndonesia, (Yogyakarta: Tiara Wacana, 1997), 144-145.

${ }^{15}$ Said Ramadhan, "Three Major Problems Confronting the World of Islam" dalam Ahmad Ibrahim (ed) Reading on Islam ini Shoutheast Asia, (Singapore Institute of South east Asian Studies, (1985), 333. 
bisnis seperti Khadijah ra dan lain sebagainya. Sedangkan dalam konteks modernitas, semangat emansipasi perempuan begitu mengelora. Sesunggguhnya perjungan gerakan feminism dan emansipasi perempuan tidak bisa tidak juga harus memotret dari perjungan muslimah terdahulu yang telah diberikan keabsahan yang begitu luar biasa dalam menjalankan profesi-profesi yang sangat berpengaruh tetapi masih tetap dalam koridor religius dan nilai-nilai Islam. Sehinggah harkat dan martabatnya sebagai perempuan tetap terjaga kemuliaanya. Dalam ajaran Islam yang menyangkut tentang perempuan mempersilahkan perempuan untuk menjadi manusia yang modern dengan menjalankan aktifitas-aktifitas sebagai manusia lainya pada umumnya, namun juga kepada peremuan untuk tetap menjaga dirinya, harga diri, martabatnya serta akhlaknya, dan yang paling fundamen adalah tetap menjaga kehambaanya kepada Allah SWT. ${ }^{16}$

Sementara itu pada masa kini, banyak permasalahan yang dialami oleh kaum perempuan dan tidak semua persoalan itu semua solusinya dapat diterima, banyak dari kalangan feminisme peremuan yang terkadang mengambil dari konsep-konsep emansipasi perempuan dari Barat tanpa ada proses seleksi terlebih dahulu dalam prespektif etika Islam, dengan dalih banyaknya persamaan hak yang semestinya juga dirasakan oleh kaum perempuan Islam mesti terkadang bertentangan dengan nilai agama Islam itu sendiri, hal ini sangat kontras jika dibandingkan dengan para filusuf muslim ketika akidah mereka bersinggungan dengan dogma dan ajaran filsafat Yunani, mereka para filusuf muslim tidak menerima seratus persen semua pemikiran filsafat Yunani, ketika ada pemikiran yang bertentangan dengan ajaran Islam mereka menyeleksi dan membuangnya, sedangkan apabila dalam pemikiran filsafat Yunani ada yang sejalan dengan semangat Islam, mereka terus mengembangkan filsafat Yunani tersebut untuk kemajuan Islam itu sendiri, dan upaya ini berhasil sehingga Islam pada waktu itu memasuki masa-masa punjak kejayaanya di Abad Pertengaha di Asia dan Eropa.

Gerakan emansipasi perempuan Islam dalam masa modern ini perlu kiranya direvitalisasi dengan meniru pola transmisi era ulama klasik ketika berdahapan dengan filsafat Helenialisme Yunani, dimana ulama klasik melakukan seleksi yang sangat ketat terhadap teks-teks maupun wacana pemikiran yang dinggap maju pada eranya. Dengan begitu semangat emansipasi perempuan Islam tetap terjaga sesuai dengan ajaran-ajaran Islam supaya gerakan emansipasi perempuan Islam tidak kebablasan menjadi semangat gerakan yang sekuler yang tidak mengindahkan etika Islam yang dijunjung oleh umat Islam. Metode yang efektif dalam membangun kesadaran gender dikalangan kaum perempuan Islam adalah dengan tetap berpegang pada dogmatika ajaran Islam yang diangap sakral, kemudian membangun kesadaran perempuan muslim akan arti penting pendidikan agar tidak terjadi perbedaan dalam konteks peranan perempuan dengan laki-laki dalam segala aspek. Perempuan tetap memainkan perananya sebagai sosok yang penting dan mulia disamping kaum laki-laki.

16 Syahrin Harahap, Islam Dinamis, 147. 


\section{Peran Perempuan dalam Pendidikan Islam}

Perbincangan mengenai persamaan hak antara kaum perempuan dengan kaum laki-laki sejak lama digaungkan oleh aktifis gender, hal ini tidak bisa dilepaskan dari kesadaran kaum perempuan mengenai arti penting pendidikan itu sendiri dalam kehidupan umat manusia khususnya dikalangan perempuan muslim dalam urusan pekerjaan, karir yang setara dengan laki-laki.

Dalam konteks sejarah Islam, paling tidak peran perempuan dalam bidang pendidikan telah dilakukan oleh Istri Nabi Muhammad Aisyah yang terkenal dengan kecerdasanya dan periwayatan beberapa hadist. Kemudian pada era dinasti Fatimiyah di Mesir mendirikan Jami' Al-Azhar sebagai cikal bala Universitas Al-Azhar Kairo Mesir.

Mengenai peran perempuan dalam bidang pendidikan Islam, Azyumadil Azra mengemukakan bahwa perhatian ulama' tentang peran penting perempuan Islam dalam bidang pendidikan dan keilmuan telah digambarkan secara menarik sebagaimana yang telah ditulis oleh seorang ulama' al-Khatib al Baghdadi sebagaimana yang ditulis dalam karanganya Tarikh Baghdad memuat beberapa bigrafi sejumlah ulama' perempuan. Begitu juga As-Sakhawi menulis beberapa ulama' apada abad ke-15 dalam Ad- Daw' al Lami' yang secara khusus tentang perempuan yang diberi judul An-Nisa' yang memuat biografi 1075 perempuan, 411 diantara berpendidikan tinggi ${ }^{17}$. Bahkan dalam karya Ibnu Hajar Ishabah fi Tamyiz al-Shahabah, Salabi memberikan data bahwa tentang jumlah ulama' perempuan mencapai 1543. Begitu juga dalam kitab Tahzib Al- Asma' karya An-Nawawi menyebutkan jumlah ulama' perempuan pada era Islam klasik jumlahnya sangat banyak. ${ }^{18}$

Dalam konteks ke-Indonesian sebenarnya ulama-ulama perempuan yang konsen dalam pendidikan Islam bisa disebutkan misalnya pada saat kerajaan Aceh pernah diperintah oleh bebeberapa Sulthanan yang mempunyai kekuatan politis juga kepakaran dalam ilmu agama Islam dan juga mempunyai perhatian yang besar terhadap keberlangsungan agama Islam melalui jalur pendidikan Islam dan Dakwa Islam. Pada abad ke-20 muncul beberpa aktifis muslimah di Indonesia seperti Nyai Achmad Dahlan dan beberapa Nyai-Nyai (ulama'-ulama' perempuan) yang berkiprah dalam pesantran tradisional.

Bahkan tokoh emansipasi perempuan Indonesia R.A Kartini menurut data yang termutakhit beliau juga pernah nyantri pada ulma' terkemuka di Jawa Tengah yang juga turut mengispirasi kesadaran perjunganya bagi pendidikan perempuan, disamping intensnya R. A Kartini dalam berinteraksi dengan teman-temanya yang berada di Belanda. Yang menjadi menarik adalah bahwa R.A Kartini sebagai bangsawan perempuan Jawa yang juga beragama Islam, juga pernah mendapatkan pendidikan di pesantren yang berakar kuat dalam kepribadinya dalam mengangkat derajat perempuan dalam pendidikan. R.A Kartini pernah belajar agama Islam kepada Kiai Soleh Darat,19

17 Azyumardi Azra, "Membongkar Peranan Perempuan dalam bidang Keilmuan", dalam Kepemimpinan Perempuan Dalam Islam, (Jakarta: JPPR, 1999), 70.

18 Ibid., 71.

19 Zainal Abidin, “Kesetaraan Gender”, 15. 
bahkan Kiai Soleh Darat menerjemahkan Al-Quran dalam bahasa Jawa itu juga karena inisiatif kegelisahan dari R.A kartini.

\section{Kesimpulan}

Sesungguhnya perjuangan kesetaraan gender sudah dilakukan sejak zaman Nabi Muhammad hingga pada masa era modern ini, meskipun begitu konteks emansipasi perempuan dan feminisme menjadi sebuah trend di dunia Barat. Saat ini, diskursus gender juga terjadi di kalangan perempuan muslim yang konsen dalam gerakan gender yang menuntut persamaan hak antara perempuan dan laki-laki dalam segala bidang.

Agama Islam mengakui persamaan hak antara perempuan dan laki-laki yang mulai dikenalkan dalam ajaran Islam melalui teks-teks Al-Qur'an dan Hadist. Sehingga tidak heran pada masa-masa keemasan peradaban Islam telah bermunculan ulama'ulama' dari kalangan perempuan.

Dalam hal pendidikan Islam, tokoh termashur dalam sejarah salah satunya adalah Aisyah RA, istri Nabi yang terkenal dengan kecerdasannya serta termasuk paling banyak yang meriwayatkan hadist, tidak hanya berhenti pada periode itu saja, pada periode selanjutnya yakni pada abad pertengahan memunculkan banyak sekali ulama'ulama' perempuan, bahkan dalam Ishabah fi Tamyiz al-Shahabah karya Ibnu Hajar, jumah ulama' pada abad pertengahan mencapai 1543.

Di Indonesia juga mempunyai tokoh yang lantang menyuarakan suara perempuan yakni RA Kartini, RA Kartini dengan lantang menyuarakan persamaan hak antara laki-laki dan perempuan, bahkan RA Kartini pernah meminta kiai Sholeh Darat untuk menerjamakan Al-Qur'an dalam bahasa Jawa supaya bisa dipahami dan dimengrti oleh masyarakat pada waktu itu.

Pendidikan yang baik tidak akan pernah tercipta tanpa melalui peran perempuan di dalamnya, karena perempuan yang sebagai seorang ibu merupakan al madrasah al ula di rumah bagi anak-anaknya, peren ibu dalam mendidik anaknya sangat penting bagi perkembangan peradaban selanjutnya , dan hal ini hanya bisa tercapai jika perempuan terutama seorang Ibu mempunyai pedidikan dan pengetahuan yang mahir dalam mendidik anaknya.

\section{DAFTAR PUSTAKA}

Abidin, Zainal. Kesetaraan Gender dan Emansipasi Perempuan dalam pendidikan Islam, Jurnal Tarbawiyah Vol. 12 No.01 edisi Januari-juni 2015.

Arivia, Gadis. Feminisme Sebuah Kata Hati. Jakarta: Kompas, 2006.

Asrohah, Hanun. Sejarah Pendidikan Islam. Jakarta: Logos, 1999.

Azra, Azyumardi. "Membongkar Peranan Perempuan dalam bidang Keilmuan", dalam Kepemimpinan “ Perempuan Dalam Islam. Jakarta: JPPR, 1999.

Fakih, Mansour. Analisis Gender \& Tranformasi Sosial. Yogyakarta: Putaka pelajar, 1996. Harahap, Syahrin. Islam Dinamis Menegakkan Nilai-Nilai Ajaran Al-Qur'an dalam Kehidupan Modern diIndonesia. Yogyakarta: Tiara Wacana, 1997.

Madjid, Nurcholis. Indonesia Kita. Jakarta: PT Gramedia Pustaka Utama, 2004. 
Muhammad, Husein. Fiqh Perempuan Refleksi Kiai atas Wacana Agama dan Gender. Yogyakarta: LKIS, 2012.

Muslikhati, Siti. Feminisme dan Pemberdayaan Perempuan dalam Timbangan Islam. Jakarta: Gema Insani, 2004.

Purwati, Eni. \& Hanun Asrohah, Bias Gender dalam Pendidikan Islam. Surabaya: Alpha, 2005.

Qutb, Muhammad. Subhat Hawl al-Islam, terj. Salah Paham Terhadap Islam. IIFSO, 1985.

Ramadhan, Said. "Three Major Problems Confronting the World of Islam" dalam Ahmad Ibrahim et. Al (ed) Reading on Islam ini Shoutheast Asia. Singapore Institute of South east Asian Studies. 1985.

Umar, Nasaruddin. Argumen Kesetaraan Jender Prespektif al-Qur'an. Jakarta: Paramadina, 1999.

Widyatama, Rendra. Bias Gender dalam Iklan Televisi. Yogyakarta: Media Press indo, 2006.

Zuhri, Muh. Hukum Islam dalam Lintasan Sejaran. Jakarta: RajaGrafindo Persada, 1996. 